Pediat. Res. 6:548-551 (1972)

Arginase

erythrocytes

genetic defect

Krebs-Hanseleit cycle liver primates urea synthesis

\title{
Arginase Deficiency in Macaca fascicularis. I. Arginase Activity and Arginine Concentration in Erythrocytes and in Liver
}

\author{
Vivian E. Shih, ${ }^{[18]}$ T. C. Jones, Harvey L. Levy, and Phyllis M. Madrgan \\ Joseph P. Kennedy, Jr. Memorial Laboratories, Neurology Service, Massachusetts General Hospital, and Department of \\ Neurology, Harvard Medical School, Boston, Massachusetts; New England Regional Primate Research Center, \\ Harvard Medical School, Southborough, Massachusetts; and Diagnostic Laboratories, State Laboratory \\ Institute, Massachusetts Department of Public Health, Boston, Massachusetts, USA
}

\section{Extract}

We have found a genetic trait of arginase deficiency in erythrocytes (RBC) of Macaca fascicularis (crabeater macaque). Measurements of arginase activities and arginine concentrations in $\mathrm{RBC}$, and information derived from breeding experiments indicated that arginase activities in RBG are $12.59 \mathrm{mmoles} / \mathrm{g}$ hemoglobin $(\mathrm{Hb}) / \mathrm{hr}$ (range: 8.36-15.24) in normal monkeys, 4.40 mmoles/g Hb/hr (sD \pm 2.37 ) in heterozygotes for this trait, and less than $0.05 \mathrm{mmoles} / \mathrm{g} \mathrm{Hb} / \mathrm{hr}$ in homozygotes for this trait. Concentrations of arginine in erythrocytes are less than $0.01 \mu \mathrm{moles} / \mathrm{ml}$ packed cells in both normal and heterozygous monkeys, and $0.975 \mu$ moles $/ \mathrm{ml}$ packed cells $(\mathrm{SD} \pm 0.556)$ in homozygous monkeys.

There are no significant differences in plasma amino acids and hepatic arginase activity in any animal.

\section{Speculation}

Study of arginase activity in RBC will be expanded to include a large number of monkeys in order to determine the incidence of arginase deficiency in RBC in this species. The possibility of using these monkeys as an animal model for study of human disease arginase deficiency (e.g., genetic engineering) will be explored.

\section{Introduction}

Very little is known regarding animal models for the human diseases that involve genetically determined amino acid metabolic abnormalities [2, 5]. In the past few years, we have been interested in finding simian primates with aminoacidopathies, by using techniques to identify possible heterozygotes and then mating selectively [6], or by screening for abnormal amino acid patterns in blood. As a result of such screening, in which the method of unidimensional paper chromatography of whole blood impregnated on filter paper has been employed [4], we found a group of Macaca fascicularis (crabeater macaque) with high concentrations of arginine in the blood. Subsequent studies have indicated that such monkeys have an inherited deficiency of arginase in erythrocytes. This report describes studies of this previously unrecognized genetic trait in simian primates.

\section{Materials and Methods}

Adult $M$. fascicularis included in the study were purchased from a dealer; these monkeys had been trapped 
in the wild in the vicinity of Kuala Lumpur, Malaysia. Infant $M$. fascicularis were bred at the New England Regional Primate Research Center.

Arginase activity in RBC was assayed by a slightly modified version of the procedure of Tomlinson and Westall [14]. Heparinized blood specimens were obtained in the morning after the animals had been fasted overnight, and the samples were immediately put and then kept on ice. Blood cells were separated from the plasma by centrifugation and were washed in physiologic saline at $4^{\circ}$. The buffy coat was removed, and the packed erythrocytes were lysed in 3 volumes of ice-cold distilled water. Arginase was activated by warming 0.1 or $0.2 \mathrm{ml}$ hemolysate, $0.15 \mathrm{ml} 0.1 \mathrm{M}$ glycine buffer, $\mathrm{pH} 9.5$, and $0.05 \mathrm{ml} 0.2 \mathrm{M} \mathrm{MnCl}_{2}$ at $37^{\circ}$ for $\mathrm{I}$ hr. One-tenth milliliter $0.5 \mathrm{~m}$ arginine solution $(\mathrm{pH}$ 9.5) was then added to initiate the reaction. The reaction was stopped exactly $120 \mathrm{sec}$ later by the addition of $1.0 \mathrm{ml} 10 \%$ trichloroacetic acid. Urea was estimated colorimetrically, using a $0.2-\mathrm{mI}$ aliquot of the supernatant fluid, according to Ratner [7]. Enzyme activity was expressed as millimoles per gram $\mathrm{Hb}$ per hour. When very low or no enzyme activity was detectable, sensitivity was increased by extending the incubation period to $10 \mathrm{~min}$ and by increasing the aliquot for urea determination to $1.0 \mathrm{ml}$. Arginase activity as low as 0.05 mmoles $/ \mathrm{g} \mathrm{Hb} / \mathrm{hr}$ was measured with confidence. Variation in enzyme activity in specimens from the same animal was $\pm 20 \%$ when measured on successive days.

Urea cycle enzymes in liver were studied in three monkeys which had different levels of arginase activity in $\mathrm{RBC}(0.05,0.45$, and $6.43 \mathrm{mmoles} / \mathrm{g} \mathrm{Hb} / \mathrm{hr})$. Specimens of liver were obtained by surgical biopsy and were then immediately homogenized in cold distilled water $(5 \% \mathrm{w} / \mathrm{v})$. Arginase, argininosuccinase, and ornithine transcarbamylase activities were assayed under the conditions described by Schimke [8, 9]. Enzyme activity was expressed as micromoles per gram wet weight per hour.

Measurements of free amino acids in plasma, hemolysate, and liver homogenate were performed by ion exchange column chromatography $[3,10]$.

\section{Results}

Arginase activity in erythrocytes of 18 monkeys ranged from 0.38 to 15.24 mmoles urea formed $/ \mathrm{g} \mathrm{Hb} / \mathrm{hr}$. No activity $(<0.05)$ was detectable in 15 monkeys. Monkeys may be categorized by the level of arginase activity into groups with high, intermediate, and nil activi-
Table I. Arginase activity and basic amino acids in erythrocytes of Macaca fascicularis

\begin{tabular}{lccc}
\hline \multicolumn{1}{c}{ Group } & $\begin{array}{c}\text { "High" } \\
(N=4)\end{array}$ & $\begin{array}{c}\text { "Intermediate" } \\
(N=14)\end{array}$ & $\begin{array}{c}\text { "Nil" } 2 \\
(N=15)\end{array}$ \\
\hline Arginase activity & 12.59 & 4.40 & $<0.05$ \\
Basic amino acids & $(8.36-15.24)$ & \pm 2.37 & \\
$\quad$ Arginine & $<0.01$ & $<0.01$ & 0.975 \\
Ornithine & 0.415 & 0.436 & \pm 0.556 \\
& $(0.329-0.511)$ & \pm 0.136 & \pm 0.04 \\
Lysine & 0.370 & 0.372 & 0.401 \\
& $(0.326-0.460)$ & \pm 0.144 & \pm 0.146 \\
\hline
\end{tabular}

1 Average and range.

2 Average \pm standard deviation.

${ }^{3}$ In millimoles per gram hemoglobin per hour.

${ }^{4}$ In micromoles per milliliter erythrocytes.
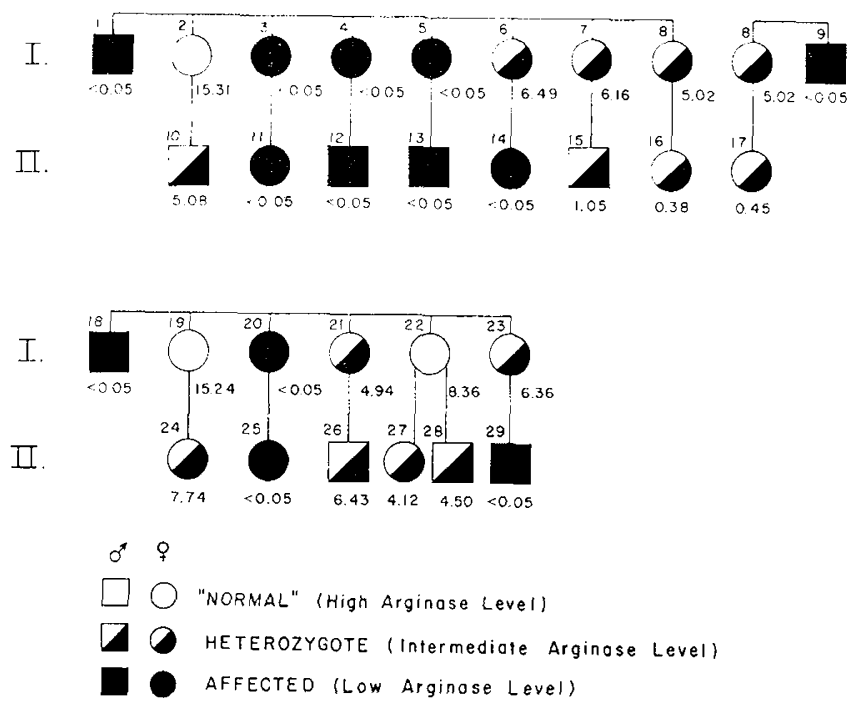

Fig. 1. Pedigree illustrating the specific mating of Macaca fascicularis with deficiency of arginase in erythrocytes (RBC). Numbers at left upper corner of symbols identify the monkeys. Figures below or at the right lower corner of symbols indicate arginase activity in $R B C$ in millimoles per gram hemoglobin per hour. Three male monkeys (I-I, I-9, and I-18) were mated with several female monkeys. I-8 was mated with two males and I-22 had two offspring. The three sires had no detectable arginase activity. Dams who had intermediate arginase activity in RBC gave birth to infant monkeys in whose $\mathrm{RBC}$ the arginase activities were in either the intermediate or the nil range. Offspring of the two dams who had no arginase activity in RBC also had no arginase activity in $\mathrm{RBC}$.

ties (Table I). Arginase activities in the groups of high and nil activity differed by more than 100-fold. The group of monkeys with no enzyme activity had increased concentration of arginine in RBC. Pedigrees 
Table II. Urea cycle enzymes in liver and erythrocytes of Macaca fascicularis

\begin{tabular}{lrrr}
\hline & \multicolumn{3}{c}{ Monkey } \\
\cline { 2 - 4 } & \multicolumn{1}{c}{$4-70$} & \multicolumn{1}{c}{$441-70$} \\
\hline Liver & & & \\
$\quad$ Arginase & & & \\
$\quad$ Argininosuccinase & & & \\
$\quad$ & 166.6 & 295.2 & 312.8 \\
$\quad \begin{array}{l}\text { Ornithine carbamyltrans- } \\
\quad \text { ferase }\end{array}$ & 8812.6 & 8089.9 & 8547.1 \\
Erythrocytes $^{1}$ & & & \\
$\quad$ Arginase $^{2}$ & 6.43 & 0.45 & $<0.05$ \\
\hline
\end{tabular}

${ }^{1}$ Enzyme activity: micromoles per gram wet weight per hour.

${ }^{2}$ Enzyme activity: millimoles per gram hemoglobin per hour.

and arginase activity in RBC of sires, dams, and offspring of certain families bred at the Primate Center are depicted in Figure 1. These findings suggest that arginase deficiency in RBC of $M$. fascicularis is a genetic trait with autosomal recessive inheritance, and that monkeys with intermediate levels of activity are heterozygous carriers whereas those with no detectable activity and high concentration of arginine in RBC are homozygotes for the trait.

The range of intermediate levels is wide. We are uncertain about the classification of two dams, I-7 and I-8, in whose RBC the arginase activities were 6.16 and $5.02 \mathrm{mmoles} / \mathrm{g} \mathrm{Hb} / \mathrm{hr}$, respectively. Erythrocytes of their offspring (II-15, II-16, and II-17) had very low arginase activities (which ranged from 0.38 to 1.05 mmoles $/ \mathrm{g} \mathrm{Hb} / \mathrm{hr}$ ) but normal arginine concentrations. We have tentatively put all in the group of heterozygotes.

Activity of hepatic arginase, as well as that of two other urea cycle enzymes in the liver, argininosuccinase and orthithine carbamyltransferase, was found to be present in adequate amounts in monkeys with and without detectable arginase activity in RBC (Table II).

Concentration of arginine in plasma was in the range of $0.086 \pm 0.037 \mu \mathrm{moles} / \mathrm{ml}$ in all monkeys regardless of the level of arginase activity. In monkeys with high or intermediate arginase activity in RBC, arginine concentration in RBC was lower than that in plasma; whereas in animals with arginase deficiency in $\mathrm{RBC}$, arginine concentration in $\mathrm{RBC}(0.975 \pm 0.556$ $\mu$ moles $/ \mathrm{ml}$ ) was much greater than in plasma (Table I). Concentrations of ornithine in RBC were lower in arginase-deficient monkeys than in those with intermediate or high levels of arginase activity. This latter finding might be anticipated inasmuch as ornithine is the product of arginine hydrolysis catalyzed by arginase.

\section{Discussion}

Arginase activity in RBG from most $M$. fascicularis was found to be much higher than that in RBC from humans (0.15-1.4 mmoles/g Hb/hr) [14]. However, in certain members of this group, activity of this enzyme was deficient in RBC but normal in liver. Data derived from specific matings have suggested that this deficiency is an autosomal recessive trait. The defect may be a polymorphism in this species. However, actual gene frequency cannot be calculated with accuracy in such a small population.

It is of interest to compare the findings in the arginase-deficient monkey with those in the human disorder, hyperargininemia. Terheggen et al. [11-13] recently described two sisters with mental retardation, spastic diplegia, seizures, hyperammonemia, increased concentrations of arginine in plasma, and deficient arginase activity in RBC. Hepatic arginase activity was not measured in these patients. A distinct difference between the human disease and the defect in the monkeys which we have studied is that in man it is associated with increased concentrations of arginine in plasma whereas monkeys have had normal concentrations of arginine in plasma. Arginine concentrations in $\mathrm{RBC}$ cannot be compared because these values for the patients were not included in the report [11-13]. Also, in contrast to human patients, animals with arginase deficiency do not have any apparent clinical abnormalities. Concentrations of ammonia in blood were normal in the affected and nonaffected monkeys studied.

The unequal distribution of arginine between plasma and RBC suggests that there is limited efflux of this amino acid from RBC. Unfortunately, there is very little published data on the transport of dibasic amino acids in RBC $[1,15]$. It may be speculated that the cell membrane of the erythrocyte is relatively impermeable to dibasic amino acids. Thus arginine, a dibasic amino acid, could not cross the cell membrane freely and would have to be metabolized to ornithine, and perhaps then converted to other compounds such as proline, in order to diffuse or to be transported into plasma. It appears that arginine in the absence of arginase activity cannot be metabolized by an alternate pathway and it becomes "trapped" within the RBC. Thus, transport of arginine, both influx and efflux, can best be studied in erythrocytes which lack arginase activity.

\section{Summary}

We found that arginase activity was deficient in erythrocytes, but normal in liver in a group of Macaca 
fascicularis (crabeater macaque). Results of breeding experiments suggest that deficiency of arginase in $\mathrm{RBC}$ is an autosomal, recessively inherited trait.

\section{References and Notes}

1. BjörNESJö, K. B.: Uptake of labelled amino acids into human crythrocytes in vitro. Clin. Chim. Acta, 11: 197 (1965).

2. Connelius, C. E.: Animal models-a neglected medical resource. New Engl. J. Med., 281: 934 (1969).

3. Efron, M. L.: Quantitative estimation of amino acids in physiological fluids using a Technicon amino acid analyzer. In: L. T. Skeggs, Jr.: Automation in Analytical Chemistry, p. 637. (Mediad Inc., New York, 1966).

4. Efron, M. L., Young, D., Moser, H. W., and MacCready, R. A.: A simple chromatographic screening test for the detection of disorders of amino acid metabolism. New Engl. J. Med., 270: 1378 (1964).

5. Jones, T. C.: Mammalian and avian models of discase in man. Fed. Proc., 28: 162 (1969).

6. Jones, T. C., Levy, H. L., MacCready, R. A., Shih, V. E., ANd Garcia, F. G.: Phenylalanine tolerance tests in simian primates. Proc. Soc. Exp. Biol. Med., 136: 1087 (1971).

7. RATNER, S.: Enzymatic synthcsis of arginine (condensing and splitting enzymes). In: S. P. Colowick and $N$. O. Kaplan: Methods in Enzymology, Vol. 2, p. 356. (Academic Press, New York, 1955).

8. Schmke, R. T.: Adaptive characteristics of urea cycle enzymes in the rat. J. Biol. Chem., 237: 459 (1962).

9. Schimke, R. T.: Arginase (rat liver). In: H. Tabor and C. W. Tabor: Methods in Enzymology, Vol. 17, p. 313. (Academic Press, New York, 1971).
10. ShiH, V. E., EFron, M. L., AND Mechanic, G. L.: Rapid shortcolumn chromatography of amino acids. A method for blood and urine specimens in the diagnosis and treatment of metabolic disease. Anal. Biochem., 20: 299 (1967).

11. Terhegien, H. G., Schwenk, A., Lowenthal, A., Van Sande, M., AND Colombo, J. P.: Argininaemia with arginase deficiency. Lancet, $i i: 134$ (1969).

12. Terrifgifin, H. G., SGhwhe, A., Lowenthal, A., Van Sande, M., ANI Colombo, J. P.: Hyperargininamie mit Arginasedefekt. Eine neue familiäre Stoffwechselströrung. X. Klin. Befunde $\%$. Kinderheilk., 107: 298 (1970).

13. Terheggen, H. G., Schwenk, A., Lowenthal, A., Van Sande, M., ANd Colombo, J. P.: Hyperargininamie mit Arginasedefckt. Eine neue familiäre StoffwechseIstörung. II. Biochem. Untersuchungen Z. Kinderheilk., 107: 313 (1970).

14. Tomlinson, S., AND Westall, R. G.: Argininosuccinic aciduria. Argininosuccinase and arginase in human blood cells. Clin. Sci., 26: 261 (1964).

15. Yunis, A. A., AND Arimura, G. K.: Amino acid transport in blood cells. Ir. Patterns of transport of some amino acids in mammalian reticulocytes and mature red blood cells. J. Lab. Clin. Med., 66: 177 (1965).

16. We thank Dr. Felix G. Garcia for performing the lives biopsics and for assistance in the nursery care of infant monkcys. Also we thank Misses Ming Ming $\mathrm{Hu}$, Miriam Carney, Petrana Peneva, Evie Barkin, and Mrs. M. Theresa Van Zant and Eloise Adams for technical assistance.

17. Supported in part by U.S. Public Health Service Research Grants nos. NS-05096 and RR-00168.

18. Requests for reprints should be addressed to: Vivian E. SHin, M.D., Massachusetts General Hospital, Boston, Mass. 02114 (USA).

19. Accepted for publication December 9, 1971. 